\title{
MEMÓRIA E FUTEBOL NO BRASIL: ESCRITAS DA VIDA DE JOGADORES BRASILEIROS ${ }^{1}$
}

\author{
Memory and football in Brazil: Life-writings of Brazilian players
}

Elcio Loureiro Cornelsen ${ }^{2}$

\begin{abstract}
RESUMO
O presente artigo visa a contribuir para o debate sobre a presença temática do futebol nos âmbitos da Literatura e da História, especificamente em obras de cunho memorialístico. Ele apresenta resultados finais de pesquisa desenvolvida nos últimos três anos, que enfocou a produção biográfica e autobiográfica em torno de figuras de destaque do futebol brasileiro, que marcaram - ou que ainda marcam - época no cenário desportivo nacional e mundial, e que contribuíram para a construção da imagem do futebol no Brasil desde seus primórdios, bem como do mito do "país do futebol", um mito cambiante e em permanente transformação. Ao todo, foram analisadas 18 obras, tendo por fundamentação teórica conceitos oriundos das áreas de História e dos Estudos Literários, sobretudo em torno dos gêneros "biografia" e "autobiografia", bem como "memória" e "história de vida". A pesquisa norteou-se pelos seguintes objetivos: (1) analisar o discurso memorialista formado a partir de obras biográficas ou autobiográficas sobre jogadores do futebol brasileiro; (2) estudar as especificidades de possíveis narrativas que alimentam o "mito" da "pátria em chuteiras" e, respectivamente, do "estilo brasileiro de jogar"; (3) por fim, contribuir para os estudos da relação entre História e Memória no campo da Teoria Literária, com enfoque nas especificidades de composição de biografias e de autobiografias.
\end{abstract}

Palavras-chave: Memória; Futebol; Escritas da Vida.

\begin{abstract}
This paper aims to contribute to the debate on the theme of football in the fields of Literature and History, specifically in memorial works. It present final results of a research developed in the last three years, that focused on the biographical and autobiographical production around prominent figures of Brazilian football that marked - or that still mark - time in the national and international sports landscape, and contributing to the construction of football image in Brazil since its inception, as well as the myth of the "country of football", a changing myth in permanent transformation. In all, 18 works were analyzed, based on theoretical concepts from the
\end{abstract}

1 Esta pesquisa foi financiada com apoio do CNPq - Conselho Nacional de Desenvolvimento Científico e Tecnológico.

2 Professor Titular da Faculdade de Letras da UFMG, atuando nas áreas de Língua e Literatura Alemã e de Letras (Graduação), e nas áreas de Teoria da Literatura e Literatura Comparada (Pós-Graduação) junto ao Programa de Pós-Graduação em Estudos Literários da UFMG; também é professor credenciado junto ao Programa de Pós-Graduação em Estudos do Lazer, da Escola de Educação Física, Fisioterapia e Terapia Ocupacional da UFMG. É bolsista de produtividade em pesquisa do CNPq. E-mail: cornelsen@letras.ufmg.br. 
areas of History and Literary Studies, especially around the genres "biography" and "autobiography", as well as "memory" and "life history". The research was guided by the following objectives: (1) to analyze the memorialist discourse formed from biographical or autobiographical works about Brazilian football players; (2) to study the specificities of possible narratives that feed the "myth" of the "homeland of cleats" and, respectively, of the "Brazilian style of football"; (3) finally, to contribute to the study of the relationship between History and Memory in the field of Literary Theory, focusing on the specificities of the composition of biographies and autobiographies.

Keywords: Memory; Football; Life-writings.

\section{Introdução}

O futebol se estabeleceu ao longo do século XX como um dos principais fenômenos culturais do Brasil, culminando com o que Nelson Rodrigues denominou emblematicamente de "a pátria em chuteiras" (RODRIGUES, 1994, p. 179-181), expressão que, nos últimos anos, tem sido questionada em sua validade.

A partir dessa perspectiva que aponta para a relevância cultural do futebol na sociedade brasileira, o presente artigo visa a contribuir para o debate sobre a presença temática do futebol nos âmbitos da Literatura e da História, especificamente em obras de cunho memorialístico. Ele apresenta resultados finais de pesquisa desenvolvida nos últimos três anos, que enfocou a produção biográfica e autobiográfica em torno de figuras de destaque do futebol brasileiro - seus verdadeiros protagonistas —, que marcaram - ou que marcam - época no cenário desportivo nacional e mundial.

A partir do objeto do estudo proposto, ou seja, as escritas da vida de jogadores brasileiros, delimitou-se um corpus de análise formado por uma série de obras de e sobre jogadores brasileiros. Para sua delimitação, basicamente, foram levados em consideração os seguintes critérios gerais: cronologia, relevância e contexto histórico. Pretendeu-se, com isso, abranger momentos do futebol brasileiro, em que determinado jogador teve seu protagonismo. 


\begin{tabular}{|c|c|c|c|}
\hline Título & Autor & Ano & Gênero \\
\hline $\begin{array}{c}\text { Charles Miller: o pai do futebol } \\
\text { brasileiro }\end{array}$ & John Robert Mills & 2005 & biografia \\
\hline Neco - o primeiro ídolo & Antonio Roque Citadini & 2001 & biografia \\
\hline $\begin{array}{l}\text { Friedenreich: a saga de um craque nos } \\
\text { primeiros tempos do futebol brasileiro }\end{array}$ & Luiz Carlos Duarte & 2012 & biografia \\
\hline Preguinho: confissões de um gigante & Waldir Barbosa Jr. & 2013 & biografia \\
\hline Nunca houve um homem como Heleno & Marcos Eduardo Neves & 2012 & biografia \\
\hline Barbosa: um gol faz cinqüenta anos & Roberto Muylaert & 2000 & biografia \\
\hline $\begin{array}{l}\text { Estrela solitária: um brasileiro chamado } \\
\text { Garrincha }\end{array}$ & Ruy Castro & 1995 & biografia \\
\hline Minha bola, minha vida & Nilton Santos & 1998 & autobiografia \\
\hline $\begin{array}{l}\text { Bombas de alegria: meio século de } \\
\text { histórias do canhão da vila }\end{array}$ & José Macia (Pepe) & 2006 & autobiografia \\
\hline Pelé, a autobiografia 3 & $\begin{array}{l}\text { Edson Arantes do } \\
\text { Nascimento }\end{array}$ & 2006 & "autobiografia" \\
\hline $\begin{array}{c}\text { Tostão: Lembranças, opiniões, reflexões } \\
\text { sobre futebol }\end{array}$ & Tostão & 1997 & autobiografia \\
\hline Rivellino & Mauricio Noriega & 2015 & biografia \\
\hline $\begin{array}{c}\text { Histórias da bola: } \\
\text { depoimento a Nilson Souza }\end{array}$ & $\begin{array}{l}\text { Paulo Roberto Falcão e } \\
\text { Nilson Souza }\end{array}$ & 1997 & "autobiografia"4 \\
\hline Zico: uma lição de vida & $\begin{array}{c}\text { Marcus Vinícius Bucar } \\
\text { Nunes }\end{array}$ & 1986 & biografia \\
\hline $\begin{array}{c}\text { Sócrates: a história e as histórias } \\
\text { do jogador mais original do futebol } \\
\text { brasileiro }\end{array}$ & Tom Cardoso & 2014 & biografia \\
\hline Romário & $\begin{array}{l}\text { Marcus Vinicius } \\
\text { Rezende de Moraes }\end{array}$ & 2009 & biografia \\
\hline $\begin{array}{l}\text { Ronaldo: glória e drama do futebol } \\
\text { globalizado }\end{array}$ & Jorge Caldeira & 2002 & biografia \\
\hline O planeta Neymar (um perfil) & Paulo Vinícius Coelho & 2014 & biografia \\
\hline
\end{tabular}

3 Essa obra não pode ser considerada como uma "autobiografia" em sentido estrito, pois Pelé contou com os jornalistas Orlando Duarte e Alex Bellos como seus redatores. Inclusive, foi publicada, primeiramente, em inglês, com o título My Autobiography (2006).

4 Trata-se de um caso semelhante, uma vez que Falcão contou com a colaboração do jornalista Nilson Souza, a quem deu depoimento. 
Pelo quadro acima, pode-se constatar que os seguintes jogadores brasileiros foram contemplados no processo de delimitação do corpus: Charles Miller, Neco (Manoel Nunes), Arthur Friedenreich, Preguinho (João Coelho Netto), Heleno de Freitas, Moacyr Barbosa, Garrincha (Manuel Francisco dos Santos), Nilton Santos, Pepe (José Macia), Pelé (Edson Arantes do Nascimento), Tostão (Eduardo Gonçalves de Andrade), Roberto Rivellino, Paulo Roberto Falcão, Zico (Artur Antunes Coimbra), Sócrates Sampaio de Souza Vieira de Oliveira, Romário de Souza Faria, Ronaldo Luis Nazário de Lima, e Neymar da Silva Santos Jr. Desse conjunto, o único que não teve passagem pela seleção brasileira foi Charles Miller, uma vez que o "pai do futebol brasileiro", como reza o mito, atuava em uma época em que a seleção ainda não tinha sido criada. Observa-se, também, que, basicamente, cinco fases do futebol brasileiro foram contempladas a partir dessa seleção de jogadores: os primórdios e a consolidação (18951945), tempos de tragédia e glória (1945-1962), tempos de glória e ufanismo (1963-1976), tempos rumo à democracia (1977-1993), e tempos de globalização (1994-2014).

Além disso, como se observa pelo quadro, os livros selecionados foram publicados entre 1986 (a biografia de Zico) e 2015 (a biografia de Rivellino). O critério cronológico foi considerado em relação à história do futebol brasileiro, desde seus primórdios às primeiras décadas do novo milênio. Privilegiou-se, assim, obras publicadas nas últimas quatro décadas, período em que, cada vez mais, se intensificou a publicação de biografias e de autobiografias de jogadores do futebol brasileiro. Entretanto, cabe aqui uma ressalva: isso não significa que biografias e autobiografias não tivessem sido escritas anteriormente. Exemplos disso são Viagem em torno de Pelé (1963), de Mário Filho, Schwarze Perle: Pelé (1969; Pérola Negra: Pelé), de Fritz Hack, ou, retornando mais atrás, o livro Mano (1924), de Coelho Netto, homenagem do ilustre escritor a seu filho, Emmanuel Coelho Netto, o "Mano", jogador do Fluminense Football Club, que falecera em 30 de setembro de 1922, aos 24 anos, em decorrência de um traumatismo sofrido no abdômen durante uma partida contra o São Cristóvão. Haveria, ainda, uma "autobiografia" inédita de Arthur Friedenreich, que o craque estava preparando para publicar pouco antes de sua morte, em 1969. Conforme matéria publicada por Bruno Freitas, o material autobiográfico de Fried foi encontrado em 2010 pelo editor César Oliveira, "durante investigação no acervo de Milton Pedrosa, antigo proprietário da Editora Gol” (FREITAS, 2013). Infelizmente, por falta de patrocínio, esse material autobiográfico, que inclui mais de 100 fotografias, permanece inédito. Inclusive, haveria um aspecto importante, caro à pesquisa desenvolvida, que diria respeito a esse material autobiográfico:

"É uma autobiografia dele [i.e., Friedenreich], certamente escrita pelo jornalista, amigo dele, Paulo Várzea. É escrito toda na primeira pessoa, numa dessas generosidades próprias dos amigos do peito, que escreveu o livro para ele, que não tinha a menor condição de produzir com aquele charme típico dos textos jornalísticos", relata o editor Cesar Oliveira. (FREITAS, 2013)

Como teremos a oportunidade de observar na parte analítica, esse não costuma ser um expediente tão raro quando se trata de relatos autobiográficos de esportistas, fato que acaba por abalar os próprios limites conceituais de "autobiografia", em que a coautoria se torna uma prática evidente, ou podendo mesmo ser omitida.

Já o critério de relevância orientou-se pelo papel que cada jogador desempenhou em seu contexto: elegeu-se as biografias de Charles Miller, Neco (Manoel Nunes), Arthur Friedenreich 
e Preguinho (João Coelho Netto), pela relevância que cada um teve, Charles Miller por auxiliar na organização do futebol em São Paulo, Neco e Arthur Friedenreich por terem se destacado no período em que foi criada a seleção brasileira, e Preguinho por ter integrado a seleção brasileira que disputou o primeiro campeonato mundial em 1930, no Uruguai. Porém, reconhece-se que, para uma definição do corpus de análise, outras obras poderiam ter sido, igualmente, selecionadas para se tratar do período dos primórdios à consolidação (1895-1945): poderia ter sido, por exemplo, incluída uma das biografias de Leônidas da Silva, Diamante eterno (1999) ou sua reedição, Diamante negro (2010), ambas de André Ribeiro, uma vez que esse jogador foi um dos maiores, senão o principal expoente da Copa de 1938, disputada na França, quando a seleção brasileira, definitivamente, entrou para a galeria das principais seleções do mundo; o mesmo vale para a biografia de Friedenreich, pois a escolha recaiu sobre Friedenreich: a saga de um craque nos primeiros tempos do futebol brasileiro (2012), de Luiz Carlos Duarte, quando havia outra opção, Friedenreich: Das vergessene Fußballgenie (2009), de Martin Curi.

O mesmo critério de relevância foi considerado na escolha das biografias de Heleno de Freitas, Moacyr Barbosa, Garrincha e Nilton Santos, e da autobiografia de José Macia (Pepe) como representantes de relatos memorialísticos sobre os tempos de tragédia e glória (19451962). Note-se que contou-se com cinco obras, para se tentar cobrir eventos relevantes do período, como as Copas de 1950, 1958 e 1962, e também o futebol dos anos 1940. Neste caso, apenas com relação a Garrincha haveria outra opção: De pernas para o ar: minhas memórias com Garrincha (2013), relato memorialístico do filho de Elza Soares, Gerson Suares, que se pautaria pela construção discursiva das memórias de si em relação ao outro. Outra biografia de um importante jogador que ficou de fora do corpus de pesquisa, mas que poderia ter sido, igualmente, integrada, seria Canhoteiro, o homem que driblou a glória (2003), de Renato Pompeu.

Ainda sobre o critério de relevância, o período referente aos tempos de glória e ufanismo (1963-1976) foi contemplado com a autobiografia de Pelé, que, como veremos na parte analítica, é um caso semelhante ao da autobiografia inédita de Friedenreich, além da autobiografia de Tostão e da biografia de Roberto Rivellino. Conforme apontado anteriormente, há várias obras de cunho memorialístico sobre Pelé, publicadas dentro e fora do Brasil. Podemos mencionar ainda, entre outras, A verdade sobre Pelé (1975), de Adriano Neyva, De Edson a Pelé: a infância do rei em Bauru (1997), de Luiz Carlos Cordeiro, Pelé: his Life and Times (2001), de Harry Harris, Pelé: minha vida em imagens (2010) e Pelé: a importância do futebol (2014), de autoria atribuída ao jogador, e Pelé: the King of Soccer (2017), de Eddy Simon. Em casos como este, o critério geral de relevância foi insuficiente para a definição da obra, de modo que outro critério específico foi necessário: para a escolha de Pelé, a autobiografia (2006), considerou-se o fato de que ela fora publicada, igualmente, em inglês — Pelé: the Autobiography —, e que contou com os jornalistas Orlando Duarte e Alex Bellos como seus "redatores" nas respectivas edições. Esse caráter sui generis da obra tornou-a interessante para o estudo, pois permitiria o debate sobre os limites do gênero "autobiografia". Além disso, devido ao número reduzido de autobiografias de jogadores de futebol em comparação ao número de biografias, a escolha recaiu sobre essa obra. Já no caso da autobiografia de Tostão, haveria duas opções: Tostão: Lembranças, opiniões, reflexões sobre futebol (1997), autobiografia que foi adotada, e Tempos vividos, sonhados e perdidos: um olhar sobre o futebol (2016), obra que não foi considerada no ato da definição do corpus, uma vez que foi lançada após a conclusão da redação do projeto de pesquisa. Outra biografia que poderia ter figurado nesse grupo seria Divino: a vida e a arte 
de Ademir da Guia (2003), de Kleber Mazziero de Souza. Porém, o craque do Palmeiras e da seleção brasileira ficou de fora devido ao interesse nessa fase recair sobre o contexto da Copa de 1970, com Pelé, Tostão e Rivellino.

Por sua vez, o critério de relevância foi, igualmente, aplicado na seleção das obras referentes aos tempos rumo à democracia (1977-1993). Neste caso, optou-se pela "autobiografia" de Paulo Roberto Falcão, assinalada aqui entre aspas por se tratar de exemplo semelhante ao da "autobiografia" de Pelé, uma vez que seu relato memorialístico, em tom de crônicas, surgiu a partir de depoimentos feitos pelo craque ao jornalista Nilson Souza, e pelas biografias de Zico e, respectivamente, de Sócrates. Quem viveu aquela época percebe o quão marcante é o trio Falcão, Zico e Sócrates, soa como uma escalação e remete à Copa de 1982 e à "Tragédia do Sarriá". Portanto, não ficariam de fora, porém, certamente, poderiam ter outras companhias que, por questões de delimitação, não foram integradas ao corpus. Sem dúvida, a obra Casagrande e seus demônios (2013), de Walter Casagrande Júnior em parceria com o jornalista Gilvan Ribeiro, outra "autobiografia", caberia muito bem nesse grupo, inclusive, num diálogo com a biografia Sócrates: a história e as histórias do jogador mais original do futebol brasileiro (2014), que integra o corpus. E em relação a Zico, a opção poderia ter recaído sobre Zico: paixão e glória de um ídolo (2000), de Lúcia Rico, ou sobre Simplesmente Zico (2014), de Priscila Ullbrich, mas a preferência recaiu sobre Zico: uma lição de vida (1986), de Marcus Vinicius Bucar Nunes, pelo simples critério de ter sido escrita e publicada quando o jogador ainda atuava.

Já o último grupo de obras, que contemplam os tempos de globalização (1994-2014), também pautou-se pelo critério de relevância, ao reunir as biografias de Romário, Ronaldo e Neymar. Para não ultrapassar o total de 18 obras, definido como critério máximo diante da exequibilidade do cronograma de pesquisa, uma figura importante do período ficou de fora: Ronaldinho. Certamente, caso houvesse a possibilidade de integrar mais obras sem comprometer o desenvolvimento da pesquisa, a biografia $O$ sorriso do futebol: Ronaldinho, o último romântico (2006), de Luca Caioli, poderia ter sido contemplada. Aliás, a lista de biografias escritas pelo biógrafo e jornalista italiano é longa, incluindo Ronaldo, Lionel Messi, Cristiano Ronaldo, Balotelli, Neymar, Mbappé, Luis Suarez, Griezmann, entre outros. Para Ronaldo e Neymar, que possuem biografias publicadas no Brasil e no exterior, inegavelmente, outros critérios teriam de ser empregados para justificar a escolha: preferiu-se Ronaldo: glória e drama do futebol globalizado (2002), de Jorge Caldeira a, por exemplo, Ronaldo: The Journey of a Genius (2005), de James Mosley, por privilegiar as publicações em Português, o mesmo valendo com relação a O planeta Neymar (um perfil) (2014), de Paulo Vinícius Coelho, e Neymar (2014), de Luca Caioli, biografia publicada em Inglês. E a escolha por Romário (2009), de Marcus Vinicius Rezende de Moraes, se deveu ao fato de que, até 2016, era a única obra publicada em Português sobre Romário de Souza Faria, sendo que, em 2017, foi lançada a obra Um olho na bola, outro no cartola: o crime organizado no futebol brasileiro, na qual Romário narra também sobre momentos de sua carreira.

Como se pode notar pelo detalhamento das escolhas pela relevância dos jogadores para a história do futebol brasileiro, o critério referente ao contexto histórico em que cada um atuou se baseou em datas, eventos e períodos específicos: a organização inicial do futebol (Charles Miller), a década de 1910 e o Campeonato Sul-Americano de 1919 (Neco e Friedenreich), o futebol na década de 1920 e a primeira Copa do Mundo de 1930 (Preguinho), os anos 1940 (Heleno), o Maracanazzo (Barbosa), a década de 1950 e os Mundiais de 1958 e 1962 
(Garrincha, Nilton Santos e Pepe), a Copa de 1970 (Pelé, Tostão e Rivellino), a Copa de 1982 e os caminhos rumo à democracia (Falcão, Zico e Sócrates) e a intensificação dos processos de globalização no futebol, cobrindo os mundiais de 1994 e 2002 (Romário e Ronaldo), e chegando até 2014, pouco antes do Mundial (Neymar).

Não obstante o fato de o corpus de análise ter sido delimitado, entre outros, pelo critério de contexto histórico em que os jogadores atuaram, torna-se relevante também, como opção, refletir sobre os contextos de produção das obras selecionadas. Conforme apontado anteriormente, os livros que integram o corpus de análise foram publicados entre 1986 e 2015. Apenas um livro foi publicado na década de 1980 (a biografia de Zico), quatro obras são da década de 1990 (a biografia de Garrincha e as autobiografias de Nilton Santos, Tostão e Falcão). Os outros 13 livros foram publicados a partir de 2000 (as biografias de Charles Miller, Neco, Barbosa, Romário e Ronaldo, e as autobiografias de José Macia [Pepe] e Pelé, entre 2000 e 2009; as biografias de Friedenreich, Preguinho, Heleno, Rivellino, Sócrates e Neymar, de 2012 a 2015).

Por um lado, a fim de enfocar, mesmo que brevemente, os contextos de produção das obras que integram o corpus de análise, deve-se levar em conta questões de ordem mercadológica. Na monografia intitulada Esporte de massa como objeto de nicho: uma análise editorial do mercado de livro de futebol (2015), Giulia Sampaio Piazzi ressalta que a publicação de livros de futebol 'é comum em anos de Copa, época em que as editoras 'disparam' uma série de títulos e aproveitam-se do momento" (PIAZZI, 2015, p. 14), pois “o evento é apontado como grande propulsor desse mercado e interfere diretamente na produção editorial sobre futebol" (2015, p. 42). Das 18 obras, sete se enquadram nesse critério, pois foram publicadas em anos de Copa, e seis obras foram lançadas em ano em que ocorreram edições da Copa das Confederações. Sem dúvida, megaeventos realizados no país, como o Pan-Americano de 2007, no Rio de Janeiro, a Copa das Confederações de 2013, a Copa do Mundo de 2014 e os Jogos Olímpicos de 2016, no Rio de Janeiro, foram momentos propícios para uma atuação maciça do mercado editorial para lançar livros de esportes em geral e, em especial, de futebol. Inclusive, há um dado estatístico levantado por Giulia Piazzi que demonstra o aumento da publicação de livros de futebol a partir de 2001: "Dos 3.040 livros publicados entre os anos de 1903 e 2013, mais da metade — mais precisamente $62 \%$ ou 1.886 livros — foi publicada após o ano de 2001" (PIAZZI, 2015, p. 42).

Por outro lado, seria insuficiente pensar o contexto de publicação das obras apenas pelo critério do mercado editorial. Muitas vezes, a chave de leitura se situa nos paratextos editoriais: apresentação editorial, nome do autor, títulos, dedicatórias, epígrafes, prefácios, posfácios, notas, agradecimentos etc. Tomemos, a seguir, dois exemplos. O primeiro deles é Sócrates, biografia do "Doutor", do jornalista Tom Cardoso, que foi publicada em 2014, ano da Copa no Brasil. O craque havia falecido em 04 de dezembro de 2011, aos 57 anos de idade. Desde 2013, o país vivia uma convulsão política, muito complexa para se descrever em poucas linhas, mas que se relacionava com a própria Copa, com movimentos contrários à sua realização, e que, nos anos seguintes, teriam consequências drásticas para a então fragilizada democracia brasileira. Assim, nada melhor do que retomar uma figura que, dentro e fora do gramado, permitiria produzir uma ressonância entre as lutas pela redemocratização do país no início dos anos 1980, e a necessidade de se refletir sobre a instabilidade política em 2013 e 2014. Não é por acaso que, em um dos paratextos, a apresentação intitulada "O prazer por personagens difíceis", o jornalista Fábio Altman define Sócrates do seguinte modo: "Sócrates, com inteligência acima da média e preocupação política incomparável à maioria dos atletas, sempre alimentou 
a imagem de rebeldia, do sujeito avesso às ordens da cartolagem de um mundo masculino oposto a qualquer postura democrática" (ALTMAN, 2014, p. 12). Esse gesto é acompanhado também pelo jornalista Mauro Beting em outro paratexto, o prefácio intitulado "Doutor, eu não me engano": "Só o que fez com o Corinthians da Democracia na redemocratização do Brasil já era para bater palmas quando muitos batiam continência" (BETING, 2014, p. 13). Em casos como este, o biografado assume uma função de exemplaridade para o contexto em que a obra foi escrita e publicada. O segundo exemplo de influência do contexto de publicação se diferencia do exemplo anterior, pois não diz respeito ao contexto político, mas sim ao contexto de produção bibliográfica de Ruy Castro. Basta um olhar para a produção entre 1993 e 1995, para constatar que o escritor, biógrafo e jornalista se ocupava do tema do futebol, algo atestado pela organização e seleção de crônicas esportivas de Nelson Rodrigues em $A$ pátria em chuteiras (1994) e À sombra das chuteiras imortais (1994), e de Mário Filho em O sapo de Arubinha: os anos de sonho do futebol brasileiro (1994). A chegada a Garrincha como figura a ser biografada se estabeleceu nesse contexto. E isso é atestado por Ruy Castro nos “Agradecimentos": “A gestação de 'Estrela solitária' teve uma história curiosa. A idéia de fazê-lo me ocorreu em 1992, logo depois da publicação de 'O anjo pornográfico"' (CASTRO 1995a, p. 492). O trabalho na biografia de Nelson Rodrigues e o envolvimento com a seleção e a organização das crônicas dos irmãos Rodrigues teriam levado Ruy Castro a gestar a ideia de escrever a biografia de Garrincha. Todavia, no último parágrafo dos "Agradecimentos", entra em cena mais um elemento: a admiração que o biógrafo nutria pelo craque há muito tempo:

\begin{abstract}
Esses últimos dois anos e meio em que convivi com a memória de Garrincha foram a retomada de uma admiração que começou num remoto domingo de novembro de 1958 quando o vi pela primeira vez no Maracanã, no jogo Botafogo 3x2 Flamengo. Foi quando descobri, olhando para dentro de mim mesmo, que até os mais ardentes torcedores do Flamengo eram Garrincha de coração. (CASTRO, 1995a, p. 493)
\end{abstract}

Entretanto, não só nos paratextos se revelam os contextos de produção das obras, pois uma análise discursiva permite, também, chegar às camadas da própria enunciação, em que marcas do contexto se evidenciam - por exemplo, na escolha de determinado tema ou mesmo de terminologia, as metaforizações etc.

Portanto, para a realização da pesquisa, foi fundamental o trabalho com literatura subsidiária que possibilitou a fundamentação teórica adequada, sobretudo em torno dos gêneros "biografia" e "autobiografia", bem como categorias que gravitam em torno do conceito de "memória”, como será exposto a seguir.

\title{
Reflexões sobre biografia, autobiografia, história de vida e memória
}

Inicialmente, partimos da definição de "biografia", termo de origem etimológica grega, que reúne em si a "escrita" (grafia) da "vida" (bio). Na escrita da vida do outro, na "biografia", sempre é apresentada uma "história de vida", e tal "história" dialoga tanto com a História, quanto com a Literatura. Teóricos de renome, entre eles, François Dosse (2009), procuram 
delimitar em suas obras as especificidades do gênero biográfico, sem, entretanto, deixar de ressaltar o caráter ficcional que, muitas vezes, perpassa tais obras. Para o teórico francês, tratase de um "gênero híbrido" (DOSSE, 2009, p. 55) que se move entre verdade e imaginação. Neste caso, o recurso à ficção surge como algo inevitável: "Não apenas o biógrafo deve apelar para a imaginação em face do caráter lacunar de seus documentos e dos lapsos temporais que procura preencher como a própria vida é um entretecido constante de memória e olvido" (DOSSE, 2009, p. 55).

As biografias, geralmente, apresentam alguns procedimentos comuns: a ordem cronológica; a centralização do foco no "herói da biografia"; o recurso às fontes e às testemunhas como acesso ao "verídico"; o método historiográfico de comparação e confirmação das fontes; o pacto de veracidade e a falta de acesso à "vida interior" do biografado. Assim, haveria nesse gênero híbrido uma indistinção epistemológica entre mimesis e vidas imaginárias. Sem dúvida, as biografias carregam em si um sentido edificante em relação à vida e à persona do biografado, a partir de uma "tensão dialética entre as dimensões factual e ficcional" (DOSSE, 2009, p. 66). E outra característica é fundamental: embora não escrita a partir de uma "exterioridade total", o narrador parece se ausentar do relato, tornando a narrativa heterodiegética (DOSSE, 2009, p. 95).

A relação entre "vontade de verdade" e "poder imaginativo" (DOSSE, 2009, p. 55) do biógrafo produz uma tensão no desenvolvimento da própria tarefa de escrever sobre a vida de outrem. Além disso, a biografia guarda semelhanças com a narrativa da história e a narrativa do romance, e pode revelar um "caráter híbrido possível entre jornalismo e história" (DOSSE, 2009, p. 122), lembrando que, em geral, os biógrafos de jogadores de futebol são jornalistas (e não historiadores). Outro ponto a ser destacado diz respeito ao "contrato de leitura" (DOSSE, 2009 , p. 95) que o biógrafo pode estabelecer com o leitor, utilizando, por exemplo, paratextos (em geral, prefácio, posfácio, apresentação, introdução etc.) nos quais revela os objetivos, as fontes e os métodos de pesquisa empregados.

A abordagem historiográfica proposta por François Dosse para situar o conceito de "biografia" ao longo dos séculos também contribui para a pesquisa no que tange à reflexão sobre o gênero na segunda metade do século XIX, quando teria ocorrido uma "proliferação de relatos biográficos que tentam articular individualidade e exemplaridade" (DOSSE, 2009, p. 169). Esse expediente da "exemplaridade" parece vigorar ainda nos dias de hoje, quando o assunto é a escrita da vida de determinada celebridade.

Por sua vez, a categoria de "ilusão biográfica" (DOSSE, 2009, p. 208) discutida por Dosse é importante, pois reforça o sentido de "biografia" como um construto discursivo, não se tratando, pois, de uma vida como ela é (ou foi), mas sim de um discurso (ilusionista) de uma vida como se ela fosse (ou tivesse sido) assim. Isso teria o potencial de produzir, no ato de leitura, o "efeito do vivido" (DOSSE, 2009, p. 410). Desse modo, torna-se fundamental o seguinte ponto de vista proposto por Dosse acerca da tarefa do biógrafo: "Reconhecendo o caráter plural, construído na narração, da identidade pessoal, o biógrafo procura estudar as metamorfoses do sentido de identidade narrativa do biografado" (DOSSE, 2009, p. 346).

A obra clássica de Philippe Lejeune, O pacto autobiográfico: de Rosseau à Internet (2008), também oferece subsídios para se pensar a relação entre memória e história, ficção e história, e também para evidenciar aspectos que dizem respeito ao caráter de construto discursivo que perpassa ambos os gêneros, bem como demais tipos textuais presentes no que o autor designa de "espaço (auto)biográfico", como cartas, ensaios, diários, relatos memorialísticos 
etc.

Nesse sentido, o conceito de "autobiografia" assume um caráter reflexivo enquanto "escrita da vida de si". Philippe Lejeune centrou suas considerações em torno da noção de "pacto autobiográfico", ou seja, uma espécie de "contrato de leitura" entre autor e leitor, sendo que autor, narrador e personagem figurariam como instâncias coincidentes (2008, p. 15). Em termos conceituais, se Lejeune, num primeiro momento, define a "autobiografia" como sendo a "narrativa retrospectiva que uma pessoa real faz de sua própria existência, quando focaliza sua história individual, em particular a história de sua personalidade" (2008, p. 16), em seguida, o teórico postula o chamado "pacto autobiográfico": a "relação de identidade entre o autor, o narrador e o personagem" (2008, p. 18).

Portanto, deduz-se que, numa biografia, tal identidade "trina" reduz-se à identidade "binária" entre autor (biógrafo) e narrador. Além disso, tanto para a biografia quanto para a autobiografia vale a seguinte máxima: "O autor se define como sendo simultaneamente uma pessoa real socialmente responsável e o produtor de um discurso" (LEJEUNE, 2008, p. 27). Além disso, ambas são "textos referenciais", pois "se propõem a fornecer informações a respeito de uma 'realidade' externa ao texto e a se submeter portanto a uma prova de verificação" (LEJEUNE, 2008, p. 43), o que implicaria um "pacto referencial". Isso demanda, portanto, uma abordagem das instâncias narrativas, sobretudo pelo emprego da primeira pessoa como uma de suas principais características, gerada pela identificação entre autor, narrador e personagem autobiográfico.

Por sua vez, Lejeune evoca, ainda, duas outras categorias caras aos estudos da biografia e da autobiografia: "modelo" e "semelhança". Conforme o autor ressalta, "na biografia é a semelhança que deve fundamentar a identidade [do biografado]" (LEJEUNE, 2008, p. 46), enquanto o "modelo" seria "o real ao qual o enunciado pretende se assemelhar" (2008, p. 44), sendo que ambos colaborariam para se estabelecer o "pacto referencial". Todo o processo, sem dúvida, pode demandar "um trabalho de elaboração propriamente literário" (2008, p. 198).

Outro aspecto destacado por Lejeune ao abordar o gênero autobiográfico, mas que diz respeito também à biografia, é o interesse despertado no leitor pelo nome daquele cuja vida está sendo narrada: "O nome, por outro lado, na medida em que figura no título do livro, programa um certo tipo de leitura: ele suscita a curiosidade biográfica e o investimento imaginário na existência de um outro" (LEJEUNE, 2008, p. 220).

Portanto, a narrativa se torna um foco de suma relevância em um estudo dessa natureza. Em geral, como nos lembra Michael Pollak, narrar uma história de vida - seja a própria ou a de outrem, colhida por entrevista como um dos possíveis procedimentos metodológicos pressupõe uma credibilidade:

Assim como uma 'memória enquadrada', uma história de vida colhida por meio da entrevista oral, esse resumo condensado de uma história social individual, é também suscetível de ser apresentada de inúmeras maneiras em função do contexto no qual é relatada. Mas assim como no caso de uma memória coletiva, essas variações de uma história de vida são limitadas. Tanto no nível individual como no nível do grupo, tudo se passa como se coerência e continuidade fossem comumente admitidas como os sinais distintivos de uma memória crível e de um sentido de identidade assegurados. (POLLAK, 1989, p. 13) 
Além disso, Pollak ressalta que as histórias de vida funcionariam também como "instrumentos de reconstrução da identidade, e não apenas como relatos factuais" (POLLAK, 1989, p. 13), completa o sociólogo austríaco, "reconstrução a posteriori, a história de vida ordena acontecimentos que balizaram uma existência" (POLLAK, 1989, p. 13). Indo na mesma direção, a historiadora Lucilia de Almeida Neves Delgado chama à atenção para o fato de que é impossível recompor o passado em sua íntegra, e que há uma necessidade de se trabalhar com fragmentos, resíduos e documentos que formam os vestígios de um determinado tempo passado:

[...] O passado apresenta-se como vidro estilhaçado de um vitral antes composto por inúmeras cores e partes. Buscar recompô-lo em sua integridade é tarefa impossível. Buscar compreendê-lo através da análise dos fragmentos, resíduos, objetos biográficos e diferentes tipos de documentação e fontes é desafio possível de ser enfrentado. (DELGADO, 2010, p. 36)

Aqui, encontramos noções fundamentais para a análise das obras selecionadas: as idéias de reconstrução da identidade e de ordenamento da vida dentro de uma lógica de coerência, e como esses aspectos se estabelecem a partir da construção narrativa, em que se considera tanto a impossibilidade de uma reconstrução plena do passado, quanto as implicações que vestígios do passado tenham sobre o processo narrativo. Aliás, como bem ressalta Lucilia Delgado, a contribuição da Memória e da História seria desempenhar uma tarefa fundamental: "buscar evitar que o ser humano perca referências fundamentais à construção das identidades coletivas" (DELGADO, 2010, p. 36).

Sem dúvida, um tema que abrange os âmbitos da Literatura, da Memória e da História sempre oferece uma oportunidade singular e relevante de refletirmos sobre os pontos de intersecção e as especificidades de cada âmbito. De acordo com a historiadora Lucilia de Almeida Neves Delgado (2010, p. 34), “[t]empo, memória, espaço e História caminham juntos. Inúmeras vezes, através de uma relação tensa de busca de apropriação e reconstrução da memória pela história". Ambas seriam "suportes básicos" (DELGADO, 2010, p. 36) para se lidar com um determinado tempo passado.

Por sua vez, Memória e História, ao lidarem com o passado, apresentam alguns pontos de intersecção enquanto "antídotos do esquecimento" (DELGADO, 2010, p. 42). Podemos afirmar, por um lado, que a Memória se relaciona com três pontos específicos: o tempo, a história e a imaginação. Outros pontos seriam marcados por sua relação com o testemunho, com a história oral, com a imagem, entre outros, além de duas características marcantes: a ação do esquecimento e a construção da narrativa pela imaginação. Por outro lado, a História também se relaciona com três pontos específicos: o tempo, a memória e as fontes ou arquivos. Igualmente, a História também se associa ao registro oral, ao testemunho, à imagem, porém, a imaginação não é a meta, mesmo que seja um elemento intrínseco, e a construção narrativa (enunciação), muitas vezes, se estabelece por estratégias de despersonalização do sujeito que enuncia como modo de apagamento de traços discursivos de subjetividade.

Além disso, o próprio conceito de "Memória" é perpassado por múltiplos significados, conforme aponta Lucília Delgado (2010, p. 39), entre outros: "ordenação e releitura de vestígios"; "retenção de elementos inerentes a conhecimentos adquiridos"; "estabelecimento de nexos entre o presente e as experiências vividas"; "evocação do passado através de lembranças"; 
"afirmação de identidades"; "atualização do passado no eterno presente"; "seleção e tensão entre o lembrar e o esquecer"; "seleção e tensão entre o narrar e o silenciar"; "evocação de utopias"; "manifestação de identidades"; "reconhecimento, ou mesmo superação, de traumas"; "reconhecimento de espaços perdidos ou reencontrados"; "reflexão sobre a experiência individual de vida".

No ensaio "Introduction: Towards Biography Theory" (2015), Joanny Moulin ressalta o fato de que, da perspectiva dos Estudos Históricos, a biografia passou a ser valorizada após os trabalhos dedicados à chamada "micro-história" (MOULIN, 2015, p. 2), proposta por Carlo Ginzburg e Giovanni Levi, entre outros. Para a pesquisa, a relevância nesse aspecto recai, justamente, sobre a possibilidade de um procedimento comparativo entre as biografias e autobiografias, no sentido de permitir que se estabeleçam relações entre elas não só em termos de vivências dos biografados e autobiografados (18 jogadores de futebol), mas também em termos de contextualização (o momento em que atuam ou atuaram).

Além disso, Joanny Moulin ressalta o fato de ainda se carecer de um maior número de estudos sobre escritas da vida que sejam sistematizados no diálogo entre as áreas — história, teoria literária, psicologia, sociologia, antropologia, filosofia etc. (MOULIN, 2015, p. 6), o que parece ser uma vantagem, justamente, ao se desenvolver pesquisa que tenha por tema o futebol, que pode ser visto como um "fato social total", de acordo com os termos postulados pelo sociólogo e antropólogo francês Marcel Mauss (1974) para definir todo fenômeno cultural de destaque em uma dada sociedade, devido à magnitude de seu significado e alcance.

Nesse sentido, a pesquisa desenvolvida e concluída recentemente contribui para esse debate em torno dos âmbitos da Memória e da História, a partir de um viés da Literatura, em que, por aproximação à Memória, muitas vezes, a imaginação é desejada e a subjetividade é discursivamente marcada, em que fontes podem servir de base para determinado relato memorialista, sem que isto seja, entretanto, uma prerrogativa. Isso não significa que haveria um primado de um âmbito sobre o outro, mas sim a concomitância de âmbitos legítimos no processo de se tentar lidar com o passado.

\section{O desenvolvimento da pesquisa sobre escritas da vida de jogadores brasileiros}

Em termos metodológicos, o desenvolvimento da pesquisa estruturou-se a partir de nove etapas. Em cada uma delas, foram executadas atividades distintas, sendo que a primeira etapa orientou-se por um breve estudo da relação entre memória e futebol no Brasil, dos primórdios aos dias atuais. Referências para essa etapa foram as seguintes obras: A dança dos deuses: futebol, cultura, sociedade (2007), de Hilário Franco Junior, Veneno Remédio: o futebol e o Brasil (2008), de José Miguel Wisnik, O futebol explica o Brasil: uma história da maior expressão popular do país (2009), de Marcos Guterman, a coletânea de ensaios The Country of Football (2014), organizada por Paulo Fontes e Bernardo Borges Buarque de Hollanda, Futebol: the Brazilian Way of Life (2002), de Alex Bellos e, respectivamente, Futebol Nation: A Footballing History of Brazil (2014), de David Goldblatt.

As próximas duas etapas da pesquisa destinaram-se ao enfoque dos conceitos e noções fundamentais para a formação de um arcabouço teórico sobre memória, história de vida, biografia e autobiografia, apresentados na seção anterior, e tiveram por referência as seguintes 
obras: A memória coletiva (2000), de Maurice Halbwachs, História e Memória (2003), de Jacques Le Goff, A memória, a história e o esquecimento (2007), de Paul Ricœur, Espaços da recordação (2011), de Aleida Assmann, o ensaio "Entre memória e história: a problemática dos lugares" (1993), de Pierre Nora, e, respectivamente, os ensaios "Memória, esquecimento e silêncio" (1989) e "Memória e memória social" (1992), de Michael Pollak.

Em sequência à segunda e à terceira etapa, orientadas pelo enfoque teórico, a quarta etapa teve por foco a leitura e análise das seguintes obras que integram o corpus de pesquisa: Charles Miller: o pai do futebol brasileiro (2005), de John Robert Mills, Neco - o primeiro ídolo (2001), de Antonio Roque Citadini, Friedenreich: a saga de um craque nos primeiros tempos do futebol brasileiro (2012), de Luiz Carlos Duarte, e Preguinho: confissões de um gigante (2013), organizada por Waldir Barbosa Jr. Tais obras dizem respeito à fase dos primórdios e da consolidação do futebol brasileiro (1895-1945), que nos permitem analisar a representação, de cunho memorialístico, acerca do referido período, com as transformações no âmbito social e político do país, vistas em sua relação com o futebol, pela chegada de um "Missionário da bola" (MILLS, 2005, p. 63) em 1894, o advento de um "esporte para poucos" (CITADINI, 2001, p. 17) em fields, o Brasil se instituindo em "uma nova escola de futebol" (DUARTE, 2012, p. 83) em 1919, com a conquista do Sul-Americano, e os obstáculos encontrados pela Seleção Brasileira no primeiro mundial, nas palavras de Preguinho: "a torcida, o frio inclemente - seis graus abaixo de zero, a desorganização de nosso selecionado" (BARBOSA JÚNIOR, 2013, p. 57)

Acompanhando o mesmo formato da etapa anterior, a quinta etapa também se destinou à leitura e análise das seguintes obras, que remetem aos tempos de tragédia e glória do futebol brasileiro (1945-1962): Nunca houve um homem como Heleno (2012), de Marcos Eduardo Neves, Barbosa: um gol faz cinqüenta anos (2000), de Roberto Muylaert, Estrela solitária: um brasileiro chamado Garrincha (1995), de Ruy Castro, as autobiografias Minha bola, minha vida (1998), de Nilton Santos e, respectivamente, Bombas de alegria: meio século de histórias do canhão da vila (2006), de José Macia (Pepe). Este grupo de obras também transmite uma série de representações referentes ao período, como a consolidação de Heleno de Freitas como o "Diamante Branco" em 1945 (NEVES, 2012, p. 101), que teria um fim trágico, em uma "década do silêncio" (MUYLAERT, 2000, p. 91), com o Maracanazo de 16 de julho de 1950, mas que alcançaria a redenção com a "vitória azul" na Suécia em 1958 (CASTRO, 1995b, p. 166) e com a Copa "vencida com certeza pelos dribles de Garrincha" (SANTOS, 1998, p. 94) nos gramados chilenos, em 1962, em uma "festa geral, que se iniciou em Brasília" (MACIA, 2006, p. 65).

Na sexta etapa da pesquisa, a fase dos tempos de glória e ufanismo (1963-1976) foi contemplada a partir da leitura e análise das seguintes obras: Pelé, a autobiografia (2006), de Edson Arantes do Nascimento, a autobiografia Tostão: Lembranças, opiniões, reflexões sobre futebol (1997), de Eduardo Gonçalves de Andrade, e a biografia Rivellino (2015), de Maurício Noriega. Esse terceiro grupo de obras nos traz representações igualmente significativas sobre a conquista do Tri e o "que significaria para o povo do nosso país" (NASCIMENTO, 2006, p. 189), o sentimento de "[c]omo era bom ser campeão do mundo" (TOSTÃO, 1997, p. 72), momento em que, segundo declaração de Rivellino a Mauricio Noriega, "os problemas enfrentados pelo país naquele período, a violência, a tortura, a censura, nada disso foi incorporado ao dia a dia da seleção" (NORIEGA, 2015, p. 61).

Já a sétima etapa contemplou obras que podem ser associadas aos tempos rumo 
à redemocratização do país (1977-1993): Histórias da bola: depoimento a Nilson Souza (1997), de Paulo Roberto Falcão e Nilson Souza, Zico: uma lição de vida (1986), de Marcus Vinícius Bucar Nunes, e Sócrates: a história e as histórias do jogador mais original do futebol brasileiro (2014), de Tom Cardoso. Esse grupo de obras marca, sobretudo, dois momentos em especial: a Copa de 1982 e o rumo à democracia. A derrota na "Batalha do Sarriá", quando "[a] concentração virou um verdadeiro velório" (FALCÃO, 1997, p. 95), nas palavras de Zico, "uma das mais injustas e cruéis realidades" (NUNES, 1986, p. 163), e se "[o]s brasileiros não votavam para presidente desde 1960!", "no Parque São Jorge tudo passou a ser decidido na urna" (CARDOSO, 2014, p. 76) com o movimento da "Democracia Corinthiana" capitaneada por Sócrates.

Ainda dentro do procedimento de leitura e análise de obras que compõem o corpus de pesquisa, a oitava etapa contemplou as seguintes obras, que se associam aos tempos atuais de globalização (1994-2014): Romário (2009), de Marcus Vinicius Rezende de Moraes, Ronaldo: glória e drama do futebol globalizado (2002), de Jorge Caldeira, e O planeta Neymar (um perfil) (2014), de Paulo Vinícius Coelho. Esse quinto e último grupo de obras abrange momentos marcantes, como as conquistas de 1994 e 2002, mas também momentos frustrantes como 1998, e também todas as dificuldades encontradas por jogadores na era de extrema mercantilização do futebol: "a língua diferente, pessoas diferentes e futebol diferente tornaram tudo muito difícil" (FARIA, 2009, p.13) para o jovem Romário quando de sua chegada ao PSV Eindhoven, da Holanda, em 1988; a grave lesão de Ronaldo, em 12 de outubro de 1999, quando "[p] or longos minutos, um silêncio completo toma conta de todo o Estádio Olímpico de Roma" (CALDEIRA, 2002, p. 276); e a realização de um sonho de muitos meninos no Brasil: em 02 de junho de 2013, Neymar "[d]esembarcou, foi direto para o estádio do time catalão, o Camp Nou, e, diante de 56 mil torcedores, que o aguardavam, fez embaixadinhas. Seguiu depois para a primeira coletiva de imprensa como jogador do Barcelona" (COELHO, 2014, p. 95).

Na próxima seção, os dados serão sistematizados e os resultados gerais serão analisados, sobretudo no que diz respeito à elaboração e constituição das obras estudadas.

\section{Sistematização e análise dos resultados gerais}

Para uma sistematização geral de resultados sobre a elaboração e a constituição das obras estudadas, foram adotados os seguintes critérios: gênero (biografia, autobiografia, relato memorialístico, reportagem, perfil etc.); construção da narrativa (enunciação e foco narrativo); depoimento (inserção de depoimentos de terceiros); elementos de paratextualidade (fotografias, gráficos, tabelas, prefácio, posfácio, apresentação, agradecimentos, apêndices, ilustrações etc.). 


\begin{tabular}{|c|c|c|c|c|}
\hline Título da Obra e Autor & Gênero & Narrativa & Depoimento & Paratexto \\
\hline $\begin{array}{l}\text { Charles Miller: o pai do } \\
\text { futebol brasileiro } \\
\text { John Mills } \\
\text { (administrador; aficionado } \\
\text { do futebol) }\end{array}$ & biografia & $3^{a}$ pessoa & $\begin{array}{l}\text { Familiares } \\
\text { Amigos } \\
\text { Jogadores }\end{array}$ & $\begin{array}{l}\text { Agradecimentos } \\
\text { Introdução } \\
\text { Fotografias } \\
\text { Documentos } \\
\text { Apêndices } \\
\text { Bibliografia }\end{array}$ \\
\hline $\begin{array}{l}\text { Neco - o primeiro ídolo } \\
\text { Antonio Roque Citadini } \\
\text { (jurista e escritor) }\end{array}$ & $\begin{array}{c}\text { biografia } \\
\text { (pesquisa } \\
\text { historiográfica } \\
\text { de Leandro } \\
\text { Antônio Gatti) }\end{array}$ & $3^{a}$ pessoa & Ausente & $\begin{array}{c}\text { Introdução } \\
\text { Fotografias } \\
\text { Documentos } \\
\text { Agradecimentos } \\
\text { Bibliografia }\end{array}$ \\
\hline
\end{tabular}

\begin{tabular}{|c|c|c|c|c|}
\hline Título da Obra e Autor & Gênero & Narrativa & Depoimento & Paratexto \\
\hline $\begin{array}{l}\text { Friedenreich: a saga de um } \\
\text { craque nos primeiros tempos } \\
\text { do futebol brasileiro } \\
\text { Luiz Carlos Duarte } \\
\text { (jornalista) }\end{array}$ & Biografia & $3^{\mathrm{a}}$ pessoa & Ausente & $\begin{array}{l}\text { Fotografias } \\
\text { Apêndices }\end{array}$ \\
\hline $\begin{array}{c}\text { Preguinho: confissões de um } \\
\text { gigante } \\
\text { Waldyr Barbosa Jr. } \\
\text { (escritor) }\end{array}$ & $\begin{array}{c}\text { biografia } \\
\text { (colaboração } \\
\text { de Waléria M. } \\
\text { P. Barbosa) }\end{array}$ & $\begin{array}{l}3^{\mathrm{a}} \text { pessoa } \\
1^{\mathrm{a}} \text { pessoa }\end{array}$ & $\begin{array}{l}\text { Preguinho } \\
\text { Waldyr } \\
\text { Barbosa } \\
\text { Familiares } \\
\text { Jornalistas }\end{array}$ & $\begin{array}{l}\text { Agradecimentos } \\
\text { Comentários } \\
\text { Fotografias } \\
\text { Documentos } \\
\text { Cronologia } \\
\text { Apêndices }\end{array}$ \\
\hline $\begin{array}{l}\text { Nunca houve um homem } \\
\text { como Heleno } \\
\text { Marcos Eduardo Neves } \\
\text { (jornalista, biógrafo e escritor) }\end{array}$ & biografia & $3^{a}$ pessoa & $\begin{array}{l}\text { Familiares } \\
\text { Amigos } \\
\text { Jogadores } \\
\text { Médicos } \\
\text { Jornalistas }\end{array}$ & $\begin{array}{c}\text { Fotografias } \\
\text { Apêndices } \\
\text { Bibliografia } \\
\text { Agradecimentos }\end{array}$ \\
\hline $\begin{array}{l}\text { Barbosa: um gol faz cinqüenta } \\
\text { anos } \\
\text { Roberto Muylaert } \\
\text { (jornalista) }\end{array}$ & $\begin{array}{c}\text { biografia } \\
\text { (reportagem) }\end{array}$ & $3^{\mathrm{a}}$ pessoa & $\begin{array}{l}\text { Barbosa } \\
\text { Familiares } \\
\text { Jogadores } \\
\text { Jornalistas } \\
\text { Roberto } \\
\text { Muylaert }\end{array}$ & $\begin{array}{c}\text { Introdução } \\
\text { Prefácio } \\
\text { Fotografias } \\
\text { Transcrição da } \\
\text { Rádio Nacional } \\
\text { Portfólio } \\
\text { Bibliografia } \\
\text { (Fontes) }\end{array}$ \\
\hline
\end{tabular}


Estrela solitária: um brasileiro

chamado Garrincha

$$
\text { Ruy Castro }
$$

(jornalista, biógrafo e escritor)

$\begin{array}{ccc} & \text { Garrincha } \\ \text { biografia } \quad 3^{\text {a }} \text { pessoa } & \begin{array}{c}\text { Familiares } \\ \text { Jogadores } \\ \text { Jornalistas }\end{array}\end{array}$

Minha bola, minha vida

$$
\text { Nilton Santos }
$$

(jogador de futebol)

Bombas de alegria: meio século de histórias do canhão

$$
\text { da vila }
$$

José Macia (Pepe)

(jogador de futebol)

Pelé, a autobiografia

Edson Arantes do Nascimento (jogador de futebol)

Tostão: Lembranças, opiniões, reflexões sobre futebol

Eduardo Gonçalves de Andrade (jogador de futebol)

autobiografia

autobiografia

$1^{\mathrm{a}}$ pessoa

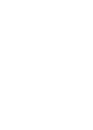

$1^{a}$ pessoa

José Macia

(Pepe)

Nilton Santos

Jogadores

(auto)

biografia

(colaboração

de Alex

Bellos e

Orlando

$1^{\mathrm{a}}$ pessoa

( $3^{\mathrm{a}}$ pessoa)

Pelé

Duarte como

"redatores")

autobiografia

$1^{\mathrm{a}}$ pessoa

Tostão
Fotografias

Documentos

Agradecimentos

Apêndices

Bibliografia

Prefácio

Depoimentos

Fotografias

Apêndices

Introdução

Fotografias

(poucas)

Entrevista

Prefácio

Fotografias

Ilustrações

Agradecimento

Prefácio

Fotografias

Nota sobre gols

Rivellino

$\begin{array}{lll}\text { biografia } & 3^{\text {a }} \text { pessoa } & \text { Familiares } \\ & 1^{\text {a }} \text { pessoa } & \text { Jogadores }\end{array}$

Maurício

Noriega
Apresentação
Fotografias
Agradecimentos
Bibliografia

autobiografia

(colaboração

e Nilson

$1^{\mathrm{a}}$ pessoa

Souza)
Falcão

Biografia

Ilustrações 


\begin{tabular}{|c|c|c|c|c|}
\hline Título da Obra e Autor & Gênero & Narrativa & Depoimento & Paratexto \\
\hline $\begin{array}{l}\text { Zico: uma lição de vida } \\
\text { Marcus Vinícius Bucar Nunes } \\
\text { (jornalista e publicitário) }\end{array}$ & Biografia & $\begin{array}{l}3^{\mathrm{a}} \text { pessoa } \\
1^{\mathrm{a}} \text { pessoa }\end{array}$ & $\begin{array}{c}\text { Zico } \\
\text { Familiares } \\
\text { Jogadores } \\
\text { Dirigentes } \\
\text { Marcus Bucar } \\
\text { Nunes }\end{array}$ & $\begin{array}{l}\text { Dedicatória } \\
\text { Agradecimentos } \\
\text { Prefácio } \\
\text { Fotografias } \\
\text { (poucas) } \\
\text { Apêndices }\end{array}$ \\
\hline $\begin{array}{l}\text { Sócrates: a história e as histórias } \\
\text { do jogador mais original do } \\
\text { futebol brasileiro } \\
\text { Tom Cardoso } \\
\text { (jornalista) }\end{array}$ & biografia & $\begin{array}{l}3^{\mathrm{a}} \text { pessoa } \\
1^{\mathrm{a}} \text { pessoa }\end{array}$ & $\begin{array}{l}\text { Sócrates } \\
\text { Treinadores } \\
\text { Dirigentes } \\
\text { Jornalistas } \\
\text { Músicos }\end{array}$ & $\begin{array}{l}\text { Apresentação } \\
\text { Prefácio } \\
\text { Fotografias } \\
\text { Apêndices } \\
\text { Agradecimentos } \\
\text { Bibliografia }\end{array}$ \\
\hline $\begin{array}{l}\text { Marcus Vinícius Rezende de } \\
\text { Moraes } \\
\text { (jornalista e radialista) }\end{array}$ & $\begin{array}{c}\text { biografia } \\
\text { (depoimentos) }\end{array}$ & $\begin{array}{l}3^{\mathrm{a}} \text { pessoa } \\
1^{\mathrm{a}} \text { pessoa }\end{array}$ & $\begin{array}{c}\text { Romário } \\
\text { Parentes } \\
\text { Amigos } \\
\text { Técnicos } \\
\text { Jogadores } \\
\text { Fisioterapeutas } \\
\text { Médicos } \\
\text { Preparadores } \\
\text { Físicos } \\
\text { Dirigentes } \\
\text { Supervisores } \\
\text { Jornalistas }\end{array}$ & $\begin{array}{l}\text { Agradecimentos } \\
\text { Auto-Retrato } \\
\text { Prefácio } \\
\text { Fotografias } \\
\text { Apêndices }\end{array}$ \\
\hline $\begin{array}{l}\text { Ronaldo: glória e drama do } \\
\text { futebol globalizado } \\
\text { Jorge Caldeira } \\
\text { (sociólogo e escritor) }\end{array}$ & biografia & $3^{\mathrm{a}}$ pessoa & Ausente & $\begin{array}{l}\text { Agradecimentos } \\
\text { Fotografias } \\
\text { Posfácio } \\
\text { Bibliografia }\end{array}$ \\
\hline $\begin{array}{c}\text { O planeta Neymar (um perfil) } \\
\text { Paulo Vinícius Coelho (PVC) } \\
\text { (jornalista) }\end{array}$ & $\begin{array}{c}\text { biografia } \\
\text { (perfil) }\end{array}$ & $3^{\mathrm{a}}$ pessoa & Ausente & $\begin{array}{l}\text { Introdução } \\
\text { Fotografias } \\
\text { Apêndices }\end{array}$ \\
\hline
\end{tabular}

O quadro de sistematização geral de resultados sobre a elaboração e a constituição das obras estudadas nos permite traçar uma série de conjecturas. Primeiramente, se pensarmos nos títulos das obras enquanto paratextos, apenas duas das 18 obras não indicam o nome ou apelido do jogador em seus respectivos títulos: Histórias da bola: depoimento a Nilson Souza, autobiografia de Paulo Roberto Falcão, e Bombas de alegria: meio século de histórias do canhão da vila, autobiografia de José Macia (Pepe). Conforme mencionado anteriormente, Philip Lejeune ressalta que o fato de o nome do biografado - algo que vale também para a autobiografia - figurar no título da obra pode programar um determinado "tipo de leitura", 
pois ele suscitaria a "curiosidade biográfica e o investimento imaginário na existência de um outro" (LEJEUNE, 2008, p. 220). Entretanto, há outras estratégias empregadas para esse fim. Com relação às duas obras indicadas, elas trazem na capa tanto as imagens quanto o nome ou o apelido dos autores - Falcão e Pepe, prescindindo, portanto, de incluí-los nos títulos.

Com relação à autoria, constata-se que predominam dois grupos específicos: por um lado, nove jornalistas, que atuam na escritura de biografias e, por outro, cinco jogadores, potenciais autores de suas autobiografias. Todavia, esse quadro é muito mais complexo do que aparenta, pois, das 18 obras analisadas, em termos de gênero textual, quatro delas são de difícil definição como biografia ou autobiografia, de acordo com os postulados propostos por François Dosse e, respectivamente, Philipp Lejeune: Neco - o primeiro ídolo, de Antonio Roque Citadini, contou com a colaboração de Leandro Antônio Gatti para a pesquisa historiográfica, sendo que seu nome consta apenas na "Introdução" (CITADINI, 2001a, p. 8); Preguinho: confissões de um gigante, de Waldyr Barbosa Jr., obra bem mais complexa, resultou de coleta de depoimentos do jogador Preguinho, feita pelo jornalista Waldyr Barbosa, que falecera sem concluir seu projeto de publicar o livro, cabendo ao filho, Waldyr Barbosa Jr., essa tarefa, que contou também com a colaboração de Waléria M. P. Barbosa, sua esposa; Pelé, a autobiografia, de Edson Arantes do Nascimento, obra publicada originalmente em inglês, que contou com os jornalistas Alex Bellos e, respectivamente, Orlando Duarte como seus "redatores", conforme consta nos agradecimentos intitulados "Obrigado" (NASCIMENTO, 2006a, p. 7); por fim, Histórias da bola: depoimento a Nilson Souza, de Paulo Roberto Falcão, que, conforme indica o subtítulo da autobiografia, se constituiu como depoimento concedido ao jornalista gaúcho Nilson Souza.

Tais ocorrências são muito ricas em sua complexidade, pois evidenciam como os limites dos gêneros textuais podem ser rompidos, chegando às raias da indeterminação em termos de sujeitos da enunciação. Para aquele que analisa esse tipo de obra, a dificuldade se situa no fato de não poder perceber o grau de interferência que, por exemplo, os "redatores" da "autobiografia" de Pelé tiveram nas formulações do próprio jogador. Isso se aplica também ao caso da biografia do jogador corinthiano Neco, pois é impossível avaliar em que medida o historiador Leandro Antônio Gatti, ao investigar a documentação, também interferiu no próprio texto de autoria de Antonio Roque Citadini. E a biografia de Preguinho também é perpassada por um grau de indeterminação em relação ao sujeito da enunciação (1), Waldir Barbosa Jr. e Waléria M. P. Barbosa no processo final do texto, que inclui também, em seção especificamente delimitada como "Comentários do idealizador sobre o projeto" (BARBOSA, 2013, p. 15-18) outro sujeito da enunciação (2), Waldyr Barbosa. O mesmo se aplica à autobiografia de Paulo Roberto Falcão, que contou com a escuta de um profissional do jornalismo, Nilson Souza. É inevitável se pensar que, nestes casos, tenha ocorrido uma espécie de "coautoria", em que profissionais da área de Jornalismo e de História são convocados a colaborar na redação das respectivas obras. Isso é, aliás, um procedimento comum no âmbito esportivo, se pensarmos em obras como It's not about the bike: My journey back to life (2000), do ciclista norte-americano Lance Armstrong, que contou com a coautoria de Sally Jenkins, e Champion's Story: A great human triumph (1981), do jockey britânico Bob Champion, que contou com a colaboração do escritor Jonathan Powell para a escrita do livro.

Ainda com relação aos gêneros textuais, nem todas as obras permitem que sejam definidas como biografias ou autobiografias stricto sensu. Das 13 biografias, três se revelam também complexas em suas composições específicas. O livro Barbosa: um gol faz cinqüenta 
anos, do jornalista Roberto Muylaert, é muito mais uma reportagem sobre o decisivo gol de Ghiggia na última partida da Copa de 1950, que decretou a derrota brasileira, bem como sobre a vida do goleiro Moacyr Barbosa até sua morte, sem que haja uma narrativa que retome um arco maior de sua vida em termos temporais, uma vez que não há a intenção de relatar sobre a infância e a formação da carreira do jogador, muito injustiçado por tudo o que ocorreu após o Maracanazo.

No mesmo sentido, o livro Romário, do jornalista e radialista Marcus Vinícius Rezende de Moraes, não é uma biografia propriamente dita, pois é um mosaico composto por inúmeros depoimentos, havendo um do próprio jogador, logo de início, na seção "AutoRetrato" (FARIA, 2009, p. 11-17), seguido de outras seções intituladas "Parentes", "Amigos", "Técnicos", "Jogadores", "Fisioterapeutas", "Médicos", "Preparadores Físicos", "Dirigentes", "Supervisores" e, por fim, "Jornalistas". Dessa forma, o autor se faz presente na organização da obra, mas não propriamente em sua enunciação nas seções indicadas. Marcus Vinícius Rezende de Moraes tem a palavra, literalmente, na seção "Agradecimentos" (MORAES, 2009b, p. 5) e em um dos quatro textos que compõem o prefácio, intitulado "Marcado para vencer" (MORAES, 2009a, p. 18-22). Além disso, o autor também foi responsável pelas entrevistas, contando com a colaboração de Denise Menezes nessa tarefa, conforme consta na ficha catalográfica do livro. Portanto, o princípio dessa obra não é o da escritura, mas sim o da escuta, outras vozes narram sobre a vida e a carreira do jogador e não aquele que figura como sendo o autor do livro.

O terceiro e último exemplo de obra que não se permite definir como "biografia" é o livro O planeta Neymar (um perfil), do jornalista Paulo Vinícius Coelho (PVC). Todavia, neste caso, o texto da orelha da capa, cuja autoria não é indicada, mas presume-se que não seja o próprio PCV, e sim algum editor, nos auxilia nessa tarefa:

Este livro não é uma biografia de Neymar Jr. — ainda seria muito cedo para tanto. Este livro é um retrato, um perfil do jogador que fez renascer o espírito ousado, improvisador e altamente técnico dos grandes atacantes brasileiros, feito por um jornalista esportivo de primeiríssima linha. (COELHO 2014)

Sem dúvida, é justamente por isso que o livro apresenta como subtítulo a expressão "um perfil". O provável editor, no texto da orelha da capa, reflete com propriedade sobre a questão do gênero textual biografia. Primeiro, de todas as obras analisadas, apenas duas se referem a um atleta ainda em atividade: além do "perfil" de Neymar, há também a biografia de Zico, de 1986. E tem sido comum a publicação desse tipo de obra, de "celebridades" muito jovens, em virtude da existência de um filão editorial. Certamente, o perfil situa o biografado até um ponto de sua vida e carreira, que está em processo de devir.

Dessa discussão em torno do gênero textual deriva também a próxima questão, que diz respeito à narrativa propriamente dita. Quando pensamos no sujeito da enunciação em uma biografia, partimos do pressuposto de que haveria predominância do foco narrativo em terceira pessoa, em que o biografado se tornaria, praticamente, uma instância correspondente a um protagonista romanesco, muitas vezes assumindo traços de heroicidade e de superação — são os casos de biografias como as de Friedenreich e Neymar —, mas também traços de tragicidade, como na reportagem biográfica sobre o goleiro Moacyr Barbosa ou na biografia de Heleno de Freitas. 
Todavia, isso não se estabelece dessa forma, uma vez que o texto pode ser composto por mais de um foco narrativo. Dentre as obras estudadas, o principal exemplo é a biografia de Romário, uma vez que, como apontado anteriormente, ela se estrutura a partir de um mosaico de depoimentos, cada um contando com seu sujeito da enunciação, que, em geral, passa da terceira para a primeira pessoa, tornando-se intradiegético, uma personagem da própria narrativa. Um exemplo evidente é a seguinte passagem da seção intitulada "Faltou união", atribuída ao jogador Sávio (Sávio Bortolini Pimentel), com quem Romário atuou pelo Club de Regatas do Flamengo:

A convivência com Romário foi muito importante para mim. Jogamos juntos, praticamente, três anos, aprendi muito com ele e, também, tive a oportunidade de contribuir para que fizesse vários gols com bolas que lhe passava, certo de que sabia o que fazer com elas. A objetividade de Romário em campo era uma de suas virtudes. (PIMENTEL, 2009, p. 141)

Mais uma vez, evidencia-se, portanto, as limitações da própria definição de gêneros textuais dessa natureza. O mesmo vale para outras obras analisadas, como, por exemplo, Preguinho: confissões de um gigante, de Waldyr Barbosa Jr., que, além de depoimento de Waldyr Barbosa, o idealizador do projeto de publicação de um livro sobre o jogador, inclui depoimentos do próprio Preguinho, de familiares e jornalistas. Isso se aplica também a Nunca houve um homem como Heleno, de Marcos Eduardo Neves, que integra depoimentos de familiares e amigos de Heleno de Freitas, de jogadores, médicos e jornalistas. A reportagem biográfica Barbosa: um gol faz cinqüenta anos, de Roberto Muylaert, também pode ser analisada por esse viés, uma vez que inclui depoimentos do próprio goleiro Moacyr Barbosa, de familiares, jogadores, jornalistas, e também do próprio autor. O mesmo ocorre em Estrela solitária: um brasileiro chamado Garrincha, de Ruy Castro, que inclui depoimentos de Garrincha, de familiares, jogadores e jornalistas. Outro exemplo desse tipo de ocorrência é Rivellino, de Maurício Noriega, que integra depoimentos do próprio jogador, de familiares, de outros jogadores e do próprio autor. A obra Zico: uma lição de vida, de Marcus Vinícius Bucar Nunes, também abre espaços para depoimentos do "Galinho de Quintino", de familiares, jogadores, dirigentes e do próprio autor. Por fim, o livro Sócrates: a história e as histórias do jogador mais original do futebol brasileiro, do jornalista Tom Cardoso, integra depoimentos do "Doutor", de treinadores, dirigentes, jornalistas e músicos.

Portanto, do conjunto de 18 obras analisadas, a metade evidencia o uso desse recurso de depoimentos em suas composições, tanto pelo caráter memorialístico e testemunhal, quanto pela natureza das fontes pesquisadas. Tal recurso, segundo Michael Pollak, pressupõe uma credibilidade (POLLAK, 1989, p. 13). Caberia, pois, estabelecer distinções entre os diversos depoimentos em cada obra, pois há aqueles que derivam de entrevistas gravadas, que, em termos metodológicos, guardam relações com a História Oral, como é o caso de Romário, de Marcus Vinícius Rezende de Moraes, mas há também aquelas obras em que os depoimentos se originaram de outras fontes, como, por exemplo, matérias publicadas na imprensa, cartas, gravações de programas de rádio e de TV etc. Aliás, um dado interessante relacionado a essa questão diz respeito ao gênero textual: das cinco autobiografias, quatro não utilizam o recurso de depoimentos, concentram-se no relato dos próprios jogadores - pelo menos, discursivamente, frente àquelas apontadas anteriormente, em que há certa indeterminação do 
sujeito da enunciação - e Minha bola, minha vida, autobiografia de Nilton Santos, inclui uma seção intitulada "Depoimentos" (SANTOS, 1998a, p. XV-XVIII), com breves notas dos campeões mundiais Gérson, Bellini, Zizinho e Vavá.

Neste ponto, entramos em uma nova questão, que diz respeito à anterior: as fontes. São nos itens que compõem parte da paratextualidade de cada obra que se pode chegar a algumas inferências sobre essa questão. Das 18 obras analisadas, a metade apresenta bibliografia que serviu de fonte para a construção dos relatos sobre cada jogador. Além destas, 17 obras contêm fotografias, com exceção da autobiografia de Paulo Roberto Falcão, Histórias da bola: depoimento a Nilson Souza, que utiliza várias ilustrações de Edgar Vasquez. E 11 obras incluem, como itens de paratextualidade, apêndices que trazem informações e dados estatísticos sobre a carreira de cada jogador, jogos, gols, conquistas etc. Tais apêndices também indicam fontes pesquisadas. Como nos lembra a historiadora Lucília Delgado, documentos como esses formam os vestígios de um determinado tempo passado (DELGADO, 2010, p. 36).

Entretanto, outros paratextos também podem aludir a prováveis fontes pesquisadas pelos biógrafos, como, por exemplo, em notas de agradecimento, presentes em 11 das 18 obras analisadas. Na obra Charles Miller: o pai do futebol brasileiro, em "Agradecimentos", John Mills agradece "a Rubens Ribeiro, historiador da Federação Paulista de Futebol e autor de 'O Caminho da Bola', excelente compêndio da história dos campeonatos paulistas entre 1902 e 1952, recheado de anedotas e reminiscências do futebol paulista" (MILLS, 2005a, p. 5). Nas páginas finais de $\mathrm{Neco}$ - o primeiro ídolo, Antonio Roque Citadini (2001b, p. 187) inclui uma nota de "Agradecimentos", que, entre outras, faz referências ao Arquivo do Estado de São Paulo e à Biblioteca Municipal Presidente Kennedy. E entre os paratextos de Preguinho: confissões de um gigante, Waldyr Barbosa Jr. inclui uma seção inicial de "Agradecimentos", assinada também por Waléria Barbosa, em que reporta o seguinte:

A João Boltshauser, gerente do Flu-Memória, que nos permitiu de imediato acesso direto aos arquivos do clube, e ao funcionário Luiz Carlos Pereira, o Luizinho, há mais de 40 anos prestando serviços ao clube, testemunha viva do caráter único de Preguinho, designado por João para nos acompanhar em busca de fotos e mais fontes que pudessem completar nosso trabalho;

A Alexandre Magno Barreto Berwanger, historiador do Fluminense por devoção e Tricolor do mais alto gabarito, por ter em conversa via rede social levantado a bola de incluir a relação completa dos jogos e gols marcados por Preguinho pelo Fluminense, o que certamente deu ainda mais relevância a esta singela homenagem a João Coelho Netto; [...] (BARBOSA JÚNIOR e BARBOSA, 2013, p. 9-10)

Além de "Agradecimentos", o estudo revelou também a presença de outros paratextos nas diversas obras analisadas: "Introdução" (em cinco), "Apresentação" (em uma), "Prefácio" (em sete) e "Posfácio" (em uma), paratextos editoriais que nem sempre são assinados pelos autores das respectivas obras. No "Posfácio" da obra Ronaldo: glória e drama do futebol globalizado, o jornalista Jorge Caldeira assim relata sobre as dificuldades de acesso ao jogador e ao processo de elaboração de seu livro: 
Sim, tentei falar com Ronaldo. Mas nunca passei da barreira de seus assessores. Enquanto tentava algo, fui juntando meu material de pesquisa, com a ajuda de minha competente sócia, Assahi Pereira Lima. Ela montou em poucos dias, com a ajuda de Kelly Mendes e Maria Silvia Lavieri Gomes, um gigantesco banco de dados sobre a carreira do jogador. Antes da informática, uma pesquisa como esta cobraria dois anos de trabalho; desta vez, foram duas semanas. (CALDEIRA, 2002a, p. 315)

Em geral, em paratextos não assinados pelo próprio autor da obra isso não ocorre, pois o foco passa a ser o biografado, como é o caso de Sócrates: a história e as histórias do jogador mais original do futebol brasileiro, de Tom Cardoso, que traz no início um "Prefácio" assinado pelo jornalista e escritor Mauro Beting, intitulado "Doutor eu não me engano" e marcado por um tom saudoso e intimista: "Aqui ta ruço, Doutor. Não to falando do Ruço, o volante cabeludo que fez um gol na invasão do Maracanã dois anos antes de você virar maloqueiro e sofredor, graças a Zeus! Ta difícil porque falta inteligência. Coragem. Técnica. Futebol. Falta você neste mundo" (BETING, 2014, p. 13). Enfim, em sua diversidade, os paratextos editoriais das obras analisadas nos permitem uma série de inferências que dizem respeito tanto à sua elaboração e composição, quanto aos próprios autores e aos biografados e autobiografados.

\section{Considerações finais}

O estudo sobre "Memória e Futebol no Brasil" nos permitiu concluir que as biografias se constituem como "gênero híbrido" (DOSSE, 2009, p. 55), bem como as autobiografias, uma vez que seus autores necessitam apelar para a imaginação diante do caráter lacunar de seus documentos e dos lapsos temporais, para entretecer seus textos. Assim, produzem uma "ilusão biográfica" (DOSSE, 2009, p. 208) como construto discursivo. Para além da indistinção epistemológica entre mimesis e vidas imaginárias, tal fato demonstra a complexidade que determinados livros de cunho memorialístico podem assumir frente a conceitos geralmente empregados para delimitar os respectivos gêneros, sobretudo no que diz respeito à narrativa enquanto construto discursivo.

A maior contribuição da pesquisa, em termos teóricos, foi colocar em foco os próprios limites dos conceitos referentes à autobiografia e à biografia enquanto gêneros textuais. Uma solução possível é adotar a categoria de "espaço (auto)biográfico" proposta pelo teórico francês Philipp Lejeune (2008, p. 16) e desenvolvida pela teórica argentina Leonor Arfuch (2009, p. 13), que inclui, justamente, obras de cunho memorialístico que não se deixam apreender como biografias ou autobiografias stricto sensu, resultando em uma indecidibilidade enquanto biografia, autobiografia, relato memorialístico, reportagem, perfil etc.

Sem dúvida, as obras estudadas constituem-se como "antídotos do esquecimento" (DELGADO, 2010, p. 42), expressão utilizada pela historiadora Lucília Delgado para refletir sobre obras de cunho memorialístico. Aliás, há um livro que não integrou o corpus de análise da pesquisa, mas que revela esse sentido no próprio título: Friedenreich: Das vergessene Fußballgenie (2009; Friedenreich: o gênio do futebol esquecido), do antropólogo alemão Martin Curi, obra ainda inédita em Português. Porém, o craque não está mais tão esquecido assim, uma vez que houve a publicação de Friedenreich: a saga de um craque nos primeiros 
tempos do futebol brasileiro (2012), de Luiz Carlos Duarte, e há a esperança de que o editor César Oliveira consiga, finalmente, encontrar patrocínio para publicar a autobiografia de "El Tigre".

A análise das obras memorialísticas em sua tessitura tanto como "textos referenciais" (LEJEUNE, 2008, p. 43), quanto como construtos discursivos, revelou que, por exemplo, no caso de biografias, para se estabelecer um pacto de veracidade, em que, supostamente, haveria a falta de acesso à "vida interior" do biografado, isso nem sempre se comprova na prática, pois alguns autores escrevem sobre os biografados como se esses fossem personagens romanescas. Exemplo maior disso é a célebre biografia de Garrincha, de Ruy Castro, onde encontramos frases como as seguintes: "Ao olhar ao redor em Bangu, Garrincha sentiu-se como que de volta ao útero. Viu-se novamente numa vila operária, cercado de gente nascida e criada em torno de uma fábrica." (CASTRO, 1995, p. 454).

Por fim, ressalta-se também o trabalho fundamental com paratextos editoriais - título, subtítulo, fotografias, gráficos, tabelas, prefácio, posfácio, apresentação, agradecimentos, dedicatória, apêndices, ilustrações, epígrafes, orelha de capa etc. - - no intuito de se ter acesso a diversas informações sobre a concepção da obra, a possível documentação consultada, o contexto histórico e de produção da obra, a relação do biógrafo com o biografado etc. Como, certa vez, afirmou Philippe Lejeune (2008, p. 43), eles são a "franja do texto impresso que, na realidade, comanda toda a leitura". Assim, foi possível lidar com o amplo corpus de análise em rua riqueza, na tentativa de se analisar os vestígios memoralísticos de mais de um século do futebol brasileiro.

\section{Referências}

\section{Literatura Primária}

ALTMAN, Fábio. O prazer por personagens difíceis. In: CARDOSO, Tom. Sócrates: a história e as histórias do jogador mais original do futebol brasileiro. Rio de Janeiro: Ed. Objetiva, 2014, p. 11-12.

BARBOSA, Waldyr. Comentários do idealizador sobre o projeto. In: BARBOSA JÚNIOR, Waldir. Preguinho: confissões de um gigante. Rio de Janeiro: Ed. do Autor, 2013, p. 15-18.

BARBOSA JÚNIOR, Waldir. Preguinho: confissões de um gigante. Rio de Janeiro: Ed. do Autor, 2013.

BARBOSA JÚNIOR, Waldir; BARBOSA, Waléria. Agradecimentos. In: BARBOSA JÚNIOR, Waldir. Preguinho: confissões de um gigante. Rio de Janeiro: Ed. do Autor, 2013, p. 9-10.

BETING, Mauro. Doutor, eu não me engano. In: CARDOSO, Tom. Sócrates: A história e as histórias do jogador mais original do futebol brasileiro. Rio de Janeiro: Objetiva, 2014, p. 13-15.

CALDEIRA, Jorge. Posfácio. In: CALDEIRA, Jorge. Ronaldo: glória e drama do futebol globalizado. Rio de 
Janeiro: Lance!; São Paulo: Ed. 34, 2002a, p. 315-316.

CALDEIRA, Jorge. Ronaldo: glória e drama do futebol globalizado. Rio de Janeiro: Lance!; São Paulo: Ed. 34, $2002 b$

CARDOSO, Tom. Sócrates: a história e as histórias do jogador mais original do futebol brasileiro. Rio de Janeiro: Ed. Objetiva, 2014.

CASTRO, Ruy. Agradecimentos. In: CASTRO, Ruy. Estrela solitária: um brasileiro chamado Garrincha. São Paulo: Companhia das Letras, 1995a, p. 489-493.

CASTRO, Ruy. Estrela solitária: um brasileiro chamado Garrincha. São Paulo: Companhia das Letras, 1995b.

COELHO, Paulo Vinícius. O planeta Neymar: um perfil. São Paulo: Ed. Paralela, 2014.

CITADINI, Antonio Roque. Introdução. In: CITADINI, Antonio Roque. Neco - o primeiro ídolo. São Paulo: Geração Editorial, 2001a, p. 7-8.

CITADINI, Antonio Roque. Neco - o primeiro ídolo. São Paulo: Geração Editorial, 2001b.

CURI, Martin. Friedenreich: Das vergessene Fußballgenie. Göttingen: Die Werktstatt, 2009.

DUARTE, Luiz Carlos. Friedenreich: a saga de um craque nos primeiros tempos do futebol brasileiro. São Caetano do SUL, SP: Casa Maior Editora, 2012.

FALCÃO, Paulo Roberto; SOUZA, Nilson. Histórias da bola. Porto Alegre: L\&PM, 1996.

FARIA, Romário de Souza. Auto-retrato. In: MORAES, Marcus Vinicius Rezende de. Romário. Rio de Janeiro: Altadena, 2009, p. 11-17.

MACIA, José (Pepe). Bombas de alegria: meio século de histórias do canhão da vila - José Macia, Pepe. Santos, SP: Realejo Edições, 2006.

MILLS, Agradecimentos. In: MILLS, John Robert. Charles Miller: o pai do futebol brasileiro. São Paulo: Panda Books, 2005a, p. 5-7.

MILLS, John Robert. Charles Miller: o pai do futebol brasileiro. São Paulo: Panda Books, 2005b.

MORAES, Marcus Vinicius Rezende de. Agradecimentos. In: MORAES, Marcus Vinicius Rezende de. Romário. Rio de Janeiro: Altadena, 2009, p. 5. 
MORAES, Marcus Vinicius Rezende de. Marcado para vencer. In: MORAES, Marcus Vinicius Rezende de. Romário. Rio de Janeiro: Altadena, 2009a, p. 18-22.

MORAES, Marcus Vinicius Rezende de. Romário. Rio de Janeiro: Altadena, 2009b.

MUYLAERT, Roberto. Barbosa: um gol faz cinqüenta anos. São Paulo: RMC Comunicação, 2000.

NASCIMENTO, Edson Arantes do. Obrigado. In: NASCIMENTO, Edson Arantes do. Pelé, a autobiografia. red. Orlando Duarte e Alex Bellos, trad. Henrique Amat Rêgo Monteiro, Rio de Janeiro: Sextante, 2006a, p. 7. (título original: My Autobiography; 2006)

NASCIMENTO, Edson Arantes do. Pelé, a autobiografia. red. Orlando Duarte e Alex Bellos, trad. Henrique Amat Rêgo Monteiro, Rio de Janeiro: Sextante, 2006b. (título original: My Autobiography; 2006)

NEVES, Marcos Eduardo. Nunca houve um homem como Heleno. Rio de Janeiro: Zahar, 2012.

NORIEGA, Mauricio. Rivellino. São Paulo: Contexto, 2015.

NUNES, Marcus Vinicius Bucar. Zico: uma lição de vida. Brasília: Offset Editora, 1986.

PIMENTEL, Sávio Bortolini. Faltou união. In: MORAES, Marcus Vinicius Rezende de. Romário. Rio de Janeiro: Altadena, 2009, p. 141-142.

SANTOS, Nilton. Depoimentos. In: SANTOS, Nilton. Minha bola, minha vida. Rio de Janeiro: Gryphius, 1998a, p. XV-XVIII.

SANTOS, Nilton. Minha bola, minha vida. Rio de Janeiro: Gryphius, 1998b.

TOSTÃO. Tostão: Lembranças, opiniões, reflexões sobre futebol. São Paulo: DBA, 1997.

\section{Literatura Subsidiária I - Memória, História, Biografia e Autobiografia}

ARFUCH, Leonor. O espaço biográfico na (re)configuração da subjetividade contemporânea. In: GALLE, Helmut et al. (orgs.). Em primeira pessoa: abordagens de uma teoria da autobiografia. São Paulo: Annablume; Fapesp; FFLCH, USP, 2009, p. 113-121.

ASSMANN, Aleida. Espaços da recordação: formas e transformações da memória cultural. Trad. Paulo Soethe, Campinas, SP: Ed. da Unicamp, 2011. 
DELGADO, Lucilia de Almeida Neves. História oral: memória, tempo, identidades. 2. ed., Belo Horizonte: Autêntica, 2010.

DOSSE, François. O desafio biográfico: escrever uma vida. Trad. Gilson César Cardoso de Souza, São Paulo: Edusp, 2009.

GALLE, Helmut et al. (orgs.). Em primeira pessoa: abordagens de uma teoria da autobiografia. São Paulo: Annablume; Fapesp; FFLCH, USP, 2009.

HALBWACHS, Maurice. A memória coletiva. trad. Beatriz Sidou, São Paulo: Centauro Editora, 2004.

LE GOFF, Jacques. Memória. In: LE GOFF, Jacques. História e Memória. trad. Irene Ferreira, Bernardo Leitão e Suzana Ferreira Borges, Campinas, SP: Ed. Unicamp, 2003, p. 419-476.

LEJEUNE, Philippe. O pacto autobiográfico: de Rousseau à internet. Trad. Jovita Maria Gerheim Noronha e Maria Inês Coimbra Guedes. Belo Horizonte: Ed. UFMG, 2008.

MOULIN, Joanny. Introduction: Towards Biography Theory. Cercles. N. 35, p. 1-11, 2015. Disponível em: https:// hal.archives-ouvertes.fr/hal-01078127/document. Acesso em: 30 jun. 2018.

NORA, Pierre. Entre memória e história: a problemática dos lugares. Projeto História, São Paulo, PUC-SP, n. 10, p. 7-28, dez. 1993.

POLLAK, Michael. Memória, esquecimento, silêncio. Estudos Históricos, Rio de Janeiro, v. 2, n. 3, p. 2-15, 1989.

POLLAK, Michael. Memória e identidade social. Estudos Históricos, Rio de Janeiro, v. 5, n. 10, p. 200-212, 1992. Disponível em: http://reviravoltadesign.com/080929_raiaviva/info/wp-gz/wp-content/uploads/2006/12/ memoria_e_identidade_social.pdf; Acesso em: 08 jul. 2009.

RICCEUR, Paul. A memória, a história, o esquecimento. Trad. Alain François et al., Campinas, SP: Ed. Da Unicamp, 2007.

\subsection{Literatura Subsidiária II - História e Memória do Futebol Brasileiro}

BELLOS, Alex. Futebol: The Brazilian Way of Life. London: Bloomsbury, 2002.

FONTES, Paulo; HOLLANDA, Bernardo Borges Buarque de (org.). The Country of Football: Politics, Popular Culture, and the Beautiful Game in Brazil. London: Hurst \& Company, 2014. 
FRANCO JÚNIOR, Hilário. A dança dos deuses: futebol, cultura, sociedade. São Paulo: Companhia das Letras, 2007.

FREITAS, Bruno. Autobiografia perdida de Friedenreich leva "não" do São Paulo e espera patrocínio. UOL Esporte: futebol. São Paulo, 10 jul. 2013. Disponível em: https:/www.uol.com.br/esporte/futebol/ultimasnoticias/2013/07/10/autobiografia-perdida-de-friedenreich-leva-nao-do-sao-paulo-e-espera-patrocinio.htm. Acesso em: 07 abr. 2020.

GOLDBLATT, David. Futebol Nation: A Footballing History of Brazil. London: Penguin Books, 2014.

GUTERMAN, Marcos. O futebol explica o Brasil: uma história da maior expressão popular do país. São Paulo: Contexto, 2009.

MAUSS, Marcel. Ensaio sobre a dádiva: forma e razão da troca nas sociedades arcaicas. In: MAUSS, Marcel. Sociologia e Antropologia. v. II, Trad. Mauro W. B. de Almeida. São Paulo: Edusp, 1974.

PASOLINI, Pier Paolo. “Il calcio ‘é’ un linguaggio con i suoi poeti e prosatori”, ln: PASOLINI, Pier Paolo. Saggi sulla letteratura e sull'arte, VoI. II, Milano: Meridiani Mondadori, 1999, p. 2545-2551.

PEDROSA, Milton. Gol de letra: o futebol na literatura brasileira. Rio de Janeiro: Editora Gol, 1967.

PIAZZI, Giulia Sampaio. Esporte de massa como objeto de nicho: Uma análise editorial do mercado de livros de futebol. TCC, Belo Horizonte: CEFET-MG, 2015.

RODRIGUES, Nelson. A pátria em chuteiras (O Globo, 02 jun. 1976). In: RODRIGUES, Nelson. A pátria em chuteiras: novas crônicas de futebol. São Paulo: Companhia das Letras, 1994, p. 179-181.

RODRIGUES, Nelson. A pátria em chuteiras: novas crônicas de futebol. São Paulo: Companhia das Letras, 1994.

RODRIGUES FILHO, Mario. O negro no futebol brasileiro. 4. ed., Rio de Janeiro: Mauad, 2003.

WISNIK, José Miguel. Veneno Remédio: o futebol e o Brasil. São Paulo: Companhia das Letras, 2008.

RECEBIDO EM: 30/03/2020

APROVADO EM: 13/04/2020 